\title{
Analisis Buku Matematika Sekolah Menengah Atas Pada Topik Turunan
}

\author{
Muhammad Taqiyuddin \\ MTs Darul Ulum, Ds. Purwogondo Kec. Kalinyamatan Kab. Jepara
}

\begin{abstract}
This study is a textbook analysis based on the view that textbook is a crucial aspect which should be recognized in the process of education development. Derivative topic covered on Indonesian eleventh grade's mathematics textbook from 2008 to 2017 was chosen to be anlyzed. Furthermore, this study attempted to provide a picture of how the mathematics textbooks covered the topics. The analysis of four textbooks: 2017, 2014, 2009, and 2008 textbooks, was carried out by applying conceptual framework and "mathematical story" theory derived from literary theory. The result showed that the 2008 book had the widest range of contexts involved in derivative concept explanation. Meanwhile, all of the books were lack of discussion on derivative as a function within graph, verbal, and physics contexts. Furthermore, the narrative analysis showed that the 2017 and 2014 textbooks provide the most promising "mathematical story" for fostering reader's curiosity. In addition, the 2017 and 2014 book also offered more multifaceted lesson in comparison with the other textbooks.
\end{abstract}

Keywords: derivative, process-object layer, mathematical story, secondary school mathematics, story arc, textbook analysis

\section{Pendahuluan}

Turunan merupakan konsep matematika yang tergabung dalam pembahasan kalkulus bersama dengan integral. Topik ini dipandang krusial untuk dipelajari di Sekolah Menengah Atas (SMA) karena pemahaman yang baik terhadap konsep ini merupakan salah satu pondasi untuk mempelajari kalkulus dan berbagai macam aplikasinya (Jones dan Watson, 2017). Selain itu, mempelajari konsep ini di SMA juga dipandang perlu untuk kesiapan belajar Kalkulus di tingkat Universitas (Blank, 1960). Hal ini didukung oleh hasil penelitian yang mengungkap dampak positif dari pembelajaran Kalkulus di SMA terhadap pembelajaran di Universitas (Robinson, 1970). Indonesia dalam hal ini sudah mengikutsertakan Kalkulus dalam kurikulum Matematika SMA (Kemendikbud, 2016) seperti halnya mayoritas negara lain di dunia (Bressoud, Ghedamsi, MartinezLuaces, dan Törner, 2016; Törner, Potari, dan Zachariades, 2014).

Beberapa penelitian membuktikan bahwa siswa mengalami kesulitan dalam mempelajari topik ini (Park, 2013; Orton, 1983) dan guru menghadapi kesulitan dalam mengajarkannya (Park, 2015). Kesulitan yang dialami oleh siswa misalnya terkait operasi Aljabar, Limit, dan representasi Turunan dalam berbagai konteks (Bressoud, dkk., 2016; Park, 2013; Orton, 1983). Perhatian yang lebih rinci dapat dilihat pada artikel Park (2015) yang menjelaskan bahwa transisi dari turunan suatu fungsi pada suatu titik ke suatu interval yang tidak dijelaskan secara rinci oleh guru dapat mengaburkan makna turunan sebagai fungsi. Kesulitan-kesulitan ini dikarenakan oleh kompleksitas definisi turunan yang melibatkan perbandingan 
selisih, limit, dan fungsi (Zandieh dan Knapp, 2006).

Upaya-upaya untuk mengatasi permasalahan tersebut dapat dilakukan dengan berbagai macam cara, misalnya dengan membuat suatu desain pembelajaran untuk mengatasi kesulitan-kesulitan dalam mempelajari Turunan (misal lih. Samuels, 2017; Verhoef, Coenders, Pieters, van Smaalen, \& Tall, 2015; Weigand, 2014). Dalam inovasi pembelajaran ini, terdapat kecenderungan implementasi teknologi (Samuels, 2017; Verhoef, dkk., 2015; Weigand, 2014). Ada pula yang mengembangkan kerangka konseptual agar dapat melihat, menganalisis dan menggambarkan pemahaman siswa tentang konsep turunan secara rinci dan komprehensif (Biza, 2017; Roorda, Vos, Drijvers, \& Goedhart, 2016; Zandieh dan Knapp, 2006). Penelitian-penelitian yang sudah dilakukan ini mempunyai peranan masing-masing dan penelitian baru masih memiliki kesempatan untuk memberikan sumbangsih tersendiri.

Penelitian ini, pada gilirannya, berupaya untuk meninjau topik turunan yang termuat dalam buku matematika SMA di Indonesia. Hal ini didasarkan atas fakta bahwa buku memiliki beberapa peran krusial dalam proses pembelajaran. Pertama, buku Matematika berkontribusi terhadap materi yang dibahas dalam pembelajaran di kelas dan bagaimana materi tersebut diajarkan (Thompson, Senk, \& Johnson, 2012; Valverde, dkk., 2002). Kedua, guru seringkali bergantung kepada buku matematika dalam proses mendesain pembelajaran yang akan dilaksanakan di kelas (Beaton et al., 1996; Sun, Kulm, \& Capraro, 2009). Ketiga, buku matematika juga dapat dipandang sebagai salah satu sumber yang memberikan kesempatan bagi siswa untuk mempelajari matematika atau yang sering disebut sebagai "opportunity to learn" (OTL) (Wijaya, Van den Heuvel-Panhuizen, \& Doorman, 2015; Fan, 2013).

Penelitian ini akan menganalisis bagaimana buku Matematika SMA menjelaskan definisi Turunan. Analisisnya akan didasarkan pada konteks apa saja yang digunakan dalam uraian definisi Turunan dan kompleksitas penjelasan definisi Turunan. Selain itu, penelitian ini juga berusaha mengungkap seperti apa pengalaman yang dimiliki oleh pembaca berdasarkan teori dari literatur. Harapannya, hasil penelitian ini mampu menjelaskan bagian mana yang bagus dari buku Matematika di Indonesia dan bagian mana yang masih perlu untuk terus diperbaiki dan dikembangkan.

\section{Kerangka Konseptual}

Pada bagian ini penulis akan memaparkan uraian tentang teori dan kerangka berpikir yang akan digunakan dalam proses analisis buku Matematika SMA pada topik Turunan. Terdapat dua bagian besar dalam kerangka berpikir ini. Yang pertama terkait dengan konteks dan kedalaman penjelasan definisi turunan sedangkan yang kedua terkait dengan narasi yang dibangun dalam uraian konsep Turunan dalam buku. Selanjutnya, pada akhir bagian, akan dipaparkan rumusan masalah yang akan diangkat pada tulisan ini.

\subsection{Turunan dalam Sudut Pandang Matematika \\ Pendidikan}

Penelitian ini mengikuti pendapat Zandieh (2000) dalam memandang konsep turunan. Pandangan Zandieh ini banyak diaplikasikan, misalnya, untuk menganalisis diskursus 
pembelajaran Turunan di kelas (Park, 2015), hasil tes siswa (Jones, 2017), maupun buku Matematika yang mencakup materi Turunan (Park, 2013). Salah satu keunggulan dari cara pandang ini terhadap konsep Turunan adalah kemampuannya untuk melihat berbagai macam konteks dari Turunan dan rincian proses dari setiap representasinya. Selanjutnya, rincian dari kerangka pemikiran ini dapat dlihat pada Tabel 1 .

Tabel 1. Kerangka Konseptual Topik Turunan menurut Zandieh

\begin{tabular}{ll}
\hline \multicolumn{2}{c}{ Turunan } \\
\hline Konteks: Representasi & \multicolumn{1}{c}{ Layer } \\
\hline 1. Grafik: Gradien dari & \\
garis singgung dari & \\
sebuah kurva pada & 1. Rasio \\
sebuah titik & 2. Limit \\
2. Verbal: Laju Perubahan & 3. Fungsi \\
3. Fisik: Kecepatan & \\
4. Simbol: Limit dari & \\
perbandingan selisih & \\
\hline
\end{tabular}

Tabel 1 menunjukkan bahwa terdapat empat konteks dimana Turunan dapat dijelaskan: grafik, verbal, fisik, dan simbol. Setiap konteks ini memiliki representasi masing-masing yang dapat dilihat di dalamnya. Ia juga menjelaskan bahwa Turunan dapat dibongkar menjadi tiga tahapan: rasio, limit, dan fungsi.

\subsection{Teks Matematika Sebagai Narasi}

Dalam upaya menelisik narasi yang ada dalam buku, penulis mengikuti pendapat Dietiker (2013) yang mengakomodasi pandangan teks buku Matematika sebagai sebuah narasi. Dalam artikelnya, dijelaskan bahwa pembaca teks Matematika memahami bacaannya dalam sebuah kronologi tertentu yang mengaitkan suatu ide Matematika dengan yang lain dari awal sampai akhir. Hal ini yang menjadikan teks Matematika dianggap mengandung "mathematical story" atau "cerita matematis". Lebih lanjut, pada kesempatan yang lain, (Dietiker, 2015) mengungkapkan bahwa konten dalam buku Matematika memiliki empat komponen yakni karakter Matematika, aksi, setting, dan plot (alur), seperti halnya yang dapat dijumpai pada teks lain seperti cerpen atau novel.

Untuk keperluan praktis dalam menganalisis teks Matematika, Dietiker dan Richman (2017) mengajukan sebuah pendapat bahwa pembaca menanyakan beberapa pertanyaan dari sebuah cerita matematis berdasarkan informasi sementara dari cerita matematis yang sudah dibaca dan melanjutkan membaca dengan membawa harapan bahwa pertanyaan-pertanyaan tersebut akan terjawab. Mereka juga menyatakan bahwa dalam proses membaca teks matematika terdapat apa yang disebut dengan "plot matematis". Ia didefinisikan sebagai perubahan dari suatu momen ke momen selanjutnya yang dirasakan oleh pembaca terhadap apa yang diketahui dan apa yang ingin diketahui pada saat beberapa pertanyaan muncul dan terjawab. Selanjutnya, plot matematis terbagi menjadi tiga bagian: aksi (bagianbagian yang membentuk kronologi tertentu dari pelajaran yang ada dalam teks), pertanyaan yang dimunculkan dalam cerita matematis, dan semua jenis progres dari pertanyaan yang muncul (disebut dengan kode plot matematis).

\subsection{Rumusan Masalah}

Rumusan masalah dari penelitian ini adalah:

a. Apa saja kategori dari kerangka konspetual yang telah 
diformulasikan oleh Zandieh (2000) yang dipenuhi oleh bukubuku Matematika Indonesia tahun 2017, 2014, 2009, dan 2008 pada topik Turunan?

b. Berdasar kerangka konseptual Zandieh (2000), bagaimana keluasan dan kedalaman materi topik Turunan pada buku Matematika Indonesia tahun 2017, 2014, 2009, dan 2008?

c. Berdasarkan kerangka berpikir Zandieh dan Richman (2017), bagaimana sajian topik Turunan pada buku Matematika Indonesia tahun 2017, 2014, 2009, dan 2008 ?

\section{Metode}

Penelitian ini menggunakan metode content analysis (Krippendorff, 2004) yang didefinisikan sebagai " $a$ research technique for making replicable and valid inferences from texts (or other meaningful matter) to the contexts of their use." Definisi tersebut kurang lebih artinya adalah sebuah teknik penelitian untuk memproduksi inferensi-inferensi yang valid dan dapat diulang prosesnya dari sebuah teks maupun sumber yang lain ke dalam konteks penggunaannya.

Selanjutnya akan diuraikan bagaimana buku-buku Matematika SMA dipilih dalam penelitian ini dan seperti apa proses analisis yang telah dilakukan oleh penulis.

\subsection{Pemilihan Buku}

Empat buku dipilih dalam penelitian ini yang merupakan buku Matematika SMA kelas XI karena topik Turunan termuat di sana. Buku-buku yang dipilih merupakan buku yang diterbitkan oleh KEMDIKBUD dan tersedia secara gratis di Internet. Dari keempat buku tersebut, terdapat dua buku yang mengikuti Kurikulum Tingkat
Satuan Pendidikan (KTSP) dan dua buku lain mengikuti Kurikulum 2013. Rincian data buku tersebut dapat dilihat pada Tabel 2.

Tabel 2. Daftar Buku Matematika SMA yang Dianalisis

\begin{tabular}{|c|c|c|}
\hline No & $\begin{array}{c}\text { Judul Buku (Tahun } \\
\text { Terbit) }\end{array}$ & Penulis \\
\hline 1 & $\begin{array}{l}\text { Mahir } \\
\text { Mengembangkan } \\
\text { Kemampuan } \\
\text { Matematika untuk } \\
\text { Kelas XI SMA/MA } \\
\text { Program IPA (2008) }\end{array}$ & $\begin{array}{l}\text { 1. Wahyudin } \\
\text { Djumanta } \\
\text { 2. R. Sudrajat }\end{array}$ \\
\hline 2 & $\begin{array}{l}\text { Wahana Matematika } \\
\text { untuk SMA/MA Kelas } \\
\text { XI Program IPA (2009) }\end{array}$ & $\begin{array}{l}\text { 1. Sutrimo } \\
\text { 2. Budi Usodo }\end{array}$ \\
\hline 3 & $\begin{array}{l}\text { Matematika } \\
\text { SMA/MA/SMK/MAK } \\
\text { Kelas XI Semester } 2 \\
(2014)\end{array}$ & $\begin{array}{l}\text { 1. Bornok } \\
\text { Sinaga } \\
\text { 2. Pardomuan } \\
\text { N.J.M. } \\
\text { 3. Sinambela } \\
\text { 4. Andri } \\
\text { Kristianto } \\
\text { Sitanggang } \\
\text { 5. Tri Andri } \\
\text { Hutapea } \\
\text { 6. Lasker } \\
\text { Pangarapan } \\
\text { Sinaga } \\
\text { 7. Sudianto } \\
\text { Manullang } \\
\text { 8. Mangara } \\
\text { Simanjorang } \\
\text { 9. Yuza } \\
\text { Terzalgi } \\
\text { Bayuzetra }\end{array}$ \\
\hline 4 & $\begin{array}{l}\text { Matematika } \\
\text { SMA/MA/SMK/MAK } \\
\text { Kelas XI (2017) }\end{array}$ & $\begin{array}{l}\text { 1. Sudianto } \\
\text { Manullang } \\
\text { 2. Andri } \\
\text { Kristianto S. } \\
\text { 3. Tri Andri } \\
\text { Hutapea } \\
\text { 4. Lasker } \\
\text { Pangarapan } \\
\text { Sinaga } \\
\text { 5. Bornok } \\
\text { Sinaga } \\
\text { 6. Mangaratua } \\
\text { Marianus S. } \\
\text { 7. Pardomuan } \\
\text { N. J. M. } \\
\text { Sinambela }\end{array}$ \\
\hline
\end{tabular}

\subsection{Analisis Buku}

Analisis yang dilakukan dalam penelitian ini mengikuti kerangka berpikir Zandieh (2000) dan Dietiker 
(2015). Kerangka konspetual yang diformulasikan oleh Zandieh (2000) membantu peneliti menganalisis bagaimana penulis buku menjelaskan konsep Turunan dalam berbagai representasi. Pada setiap representasi, penulis akan menganalisis lebih lanjut apakah terdapat tiga tahapan (process-object layer) sesuai yang diungkapkan oleh Zandieh (2000). Proses analisis dibantu dengan memberikan tanda centang pada kolom dan baris di Tabel 3.

Tabel 3. Tabel Panduan Analisis dengan Kerangka Zandieh

\begin{tabular}{|c|c|c|c|}
\hline \multirow{2}{*}{ Konteks } & \multicolumn{3}{|c|}{ Process-Object Layer } \\
\hline & Rasio & Limit & Fungsi \\
\hline $\begin{array}{l}\text { Grafik } \\
\text { (Gradien) }\end{array}$ & & & \\
\hline $\begin{array}{l}\text { Verbal } \\
\text { (Laku } \\
\text { Perubahan) }\end{array}$ & & & \\
\hline $\begin{array}{l}\text { Fisik } \\
\text { (Kecepatan) }\end{array}$ & & & \\
\hline $\begin{array}{l}\text { Simbol } \\
\text { (Perbandingan } \\
\text { Selisih) }\end{array}$ & & & \\
\hline
\end{tabular}

Dengan menggunakan panduan Tabel diatas kami melihat keluasan dan kedalaman materi topik Turunan. Keluasan materi dilihat dari berapa banyak konteks yang dicakup oleh suatu buku, sedangkan kedalaman materi dilihat dari Process-Object Layer.

Selain itu, analisis narasi dilaksanakan berdasar Dietiker dan Richman (2017). Meskipun demikian, pada laporan penelitian ini, peneliti menggunakan dua karakteristik dari plot matematis saja: aksi dan pertanyaan yang dimunculkan dalam cerita matematis. Aksi disajikan pada kolom sedangkan pertanyaan disajikan pada baris. Dengan bantuan matriks tersebut, peneliti menganalisis apakah sebuah pertanyaan dimunculkan atau dibahas dalam sebuah aksi, atau tidak (lihat Tabel 6, 8,dan 10). Cell yang diwarnai abu-abu menunjukkan bahwa sebuah pertanyaan sedang dibahas: diformulasikan, dijawab sebagian, atau dijawab secara sempurna. Banyaknya cell yang diwarnai pada suatu baris menunjukkan intensitas pembahasan sebuah pertanyaan yang disebut dengan "story arc" (Dietiker dan Richman, 2017).

Menurut mereka, story arc memiliki dua karakteristik: panjang dan tebal. Dua karakteristik ini memiliki dampak tertentu terhadap pengalaman pembaca. Misalnya, suatu buku, katakanlah buku A, memiliki story arc yang lebih panjang daripada buku lain, katakanlah buku B. Menurut pandangan mereka, buku A memiliki kesempatan lebih besar untuk menumbuh kembangkan rasa penasaran dan ingin tahu pembaca.

\section{Hasil dan Pembahasan}

Bagian ini akan menjelaskan hasil analisis yang telah dilakukan. Bagian pertama menjelaskan tentang kedalaman dan keluasan uraian topik Turunan di keempat buku. Hasil analisis yang telah dilaksanakan dapat digambarkan dalam sebuah matriks yang dapat dilihat pada Tabel 4 .

\subsection{Keluasan dan Kedalaman Materi}

Buku tahun 2017 dan 2014 identik dalam hal keluasan dan kedalaman penjelasan materi sehingga diletakkan dalam bagian yang sama. Satu kesamaan dari keempat buku yang dianalisis adalah sama-sama menjelaskan topik Turunan pada konteks simbol dalam tiga lapisan: rasio, limit, dan fungsi. Selain itu, kesamaan lain adalah keempat buku tidak ada yang menjelaskan secara lengkap semua kategori yang ada 
dalam kerangka Zandieh. Jika kita beri bobot pada setiap cell dengan 1, maka nilai maksimal yang dapat dicapai adalah 12. Dengan menghitung persentase dari bagian cell yang dicentang, maka kita peroleh data: Buku 2017, 2014, dan 2009 memperoleh 42\%, sedangkan buku 2008 memperoleh 58\%. Artinya, semua buku hanya mampu mengakomodasi sekitar setengah dari semua kemungkinan penjabaran topik Turunan.

Dalam aspek keluasan pembahasan, ternyata buku tahun 2008 memiliki pembahasan yang paling luas diantara yang lain. Buku ini menjelaskan topik Turunan dalam tiga konteks: simbol, fisik, dan grafik. Hal ini menjadi menarik karena buku ini merupakan buku tertua diantara buku yang lain. Di lain pihak, buku yang lain hanya mengakomodasi dua konteks. Buku 2017 dan 2014 mencakup konteks grafik dan simbol, sedangkan buku 2009 mencakup konteks verbal dan simbol. Dengan melihat urutan waktu terbitnya buku, ada kecenderungan pemaparan materi Turunan yang semakin menyerupai pelajaran Analisis Real yang menitik beratkan pada kompleksitas dan presisi dalam aspek simbol dan grafik.

Dalam hal kedalaman materi, keempat buku menjelaskan tiga tahapan dalam konteks simbol. Dalam konteks lain, paling banyak ada dua Process-Object Layer yang dicakup. Pada konteks grafik, buku tahun 2008, 2014, dan 2017 memaparkan aspek rasio dan limit. Pada konteks verbal, hanya buku tahun 2009 yang menjelaskan topik Turunan dalam aspek rasio dan limit. Pada konteks fisik, hanya buku tahun 2008 yang memaparkan penjelasan konsep turunan dalam aspek rasio dan limit. Jika ketiga aspek dari Process-Object Layer dibandingkan, maka aspek fungsi yang paling sedikit dibahas di seluruh buku.

Tabel 4. Hasil Analisis dengan Kerangka Zandieh

\begin{tabular}{cccc}
\hline \multirow{2}{*}{$\begin{array}{c}\text { Konteks } \\
\text { (Representasi) }\end{array}$} & \multicolumn{3}{c}{ Process-Object Layer } \\
\cline { 3 - 4 } 2017 dan 2014 & Limit & Fungsi \\
\hline $\begin{array}{c}\text { Grafik } \\
\text { (Gradien) }\end{array}$ & $\checkmark$ & $\checkmark$ & - \\
\hline $\begin{array}{c}\text { Verbal } \\
\text { (Laku }\end{array}$ & - & - & - \\
Perubahan) & & & \\
\hline $\begin{array}{c}\text { Fisik } \\
\text { (Kecepatan) }\end{array}$ & - & - & - \\
\hline $\begin{array}{c}\text { Simbol } \\
\text { (Perbandingan } \\
\text { Selisih) }\end{array}$ & $\checkmark$ & $\checkmark$ & $\checkmark$ \\
\hline $\begin{array}{c}\text { Grafik } \\
\text { (Gradien) }\end{array}$ & - & - & - \\
\hline $\begin{array}{c}\text { Verbal } \\
\text { (Laku } \\
\text { Perubahan) }\end{array}$ & $\checkmark$ & $\checkmark$ & - \\
\hline $\begin{array}{c}\text { Fisik } \\
\text { (Kecepatan) }\end{array}$ & - & - & - \\
\hline $\begin{array}{c}\text { Simbol } \\
\text { (Perbandingan } \\
\text { Selisih) }\end{array}$ & $\checkmark$ & $\checkmark$ & $\checkmark$ \\
\hline $\begin{array}{c}\text { Grafik } \\
\text { (Gradien) }\end{array}$ & $\checkmark$ & $\checkmark$ & - \\
\hline $\begin{array}{c}\text { Verbal } \\
\text { (Laku } \\
\text { Perubahan) }\end{array}$ & - & - & - \\
\hline $\begin{array}{c}\text { Fisik } \\
\text { (Kecepatan) }\end{array}$ & $\checkmark$ & $\checkmark$ & - \\
\hline $\begin{array}{c}\text { Simbol } \\
\text { (Perbandingan } \\
\text { Selisih) }\end{array}$ & $\checkmark$ & $\checkmark$ & $\checkmark$ \\
\hline & & & \\
\hline
\end{tabular}

\subsection{Analisis Cerita Matematis}

Selanjutnya, akan dipaparkan hasil analisis berdasar kerangka berpikir Dietiker dan Richman (2017) yang dapat dilihat pada Tabel 5-10. Tabel 5, 6, dan 7 menunjukkan semua pertanyaan yang mungkin muncul saat pembaca membaca teks. Di lain pihak, Tabel 8, 9, dan 10 menunjukkan story arc.

Tabel 5 menunjukkan bahwa buku 2017 dan buku 2014 memiliki pertanyaan sebanyak 22. Jumlah ini paling banyak jika dibandingkan dengan buku-buku yang lain. Buku 2009 hanya memiliki tujuh pertanyaan, sedangkan buku 2008 
memiliki 18. Artinya, istilah Matematika atau ide Matematika yang muncul pada buku 2017 dan 2014 lebih banyak daripada bukubuku yang lain. Misalnya, terdapat istilah analisis dan garis normal yang muncul pada buku 2017 dan 2014 yang tidak ditemukan di buku yang lain. Lebih lanjut, hal ini juga menunjukkan bahwa buku 2017 dan 20014 menjelaskan konsep Turunan dengan cara yang lebih detail dibanding buku lain. Di sisi lain, buku 2009 memuat penjelasan topik Turunan yang paling sederhana. Hal ini bisa dilihat dari, misalnya, fakta bahwa perbedaan notasi Leibniz dan Newton tidak dibahas pada buku tersebut.

Tabel 5. Pertanyaan yang Muncul pada Buku 2017 dan 2014

\begin{tabular}{|c|c|}
\hline No & Pertanyaan \\
\hline 1 & Apa aplikasi dari konsep turunan? \\
\hline 2 & Apa itu analisis? \\
\hline 3 & $\begin{array}{l}\text { Apa itu kemonotonan, kecekungan, } \\
\text { pengoptimalan, dan titik belok? }\end{array}$ \\
\hline 4 & Apa itu garis singgung? \\
\hline 5 & Apa kaitan garis singung dengan turunan? \\
\hline 6 & $\begin{array}{l}\text { Apa kaitan permainan ski dengan garis } \\
\text { singung? }\end{array}$ \\
\hline 7 & $\begin{array}{l}\text { Apa kaitan antara beberapa garis dan kurva } \\
\text { dengan permainan ski? }\end{array}$ \\
\hline 8 & $\begin{array}{l}\text { Bagaimana visual ini mampu } \\
\text { menggambarkan konsep garis singgung? }\end{array}$ \\
\hline 9 & Mengapa dinamakan garis normal? \\
\hline 10 & Mengapa dinamakan garis singgung? \\
\hline 11 & Mengapa dinamakan garis sekan? \\
\hline 12 & Bagimana garis sekan tiba-tiba muncul? \\
\hline 13 & $\begin{array}{l}\text { Apa yang akan terjadi dengan gradien garis } \\
\text { sekan? }\end{array}$ \\
\hline 14 & $\begin{array}{l}\text { Apa fungsi definisi gradien sekan terhadap } \\
\text { garis singgung? }\end{array}$ \\
\hline 15 & $\begin{array}{l}\text { Apakah garis singgung juga merupakan garis } \\
\text { sekan? }\end{array}$ \\
\hline 16 & Apa itu fungsi kontinu? \\
\hline 17 & $\begin{array}{l}\text { Apakah kontinu menjadi syarat agar sebuah } \\
\text { fungsi dapat diturunkan? }\end{array}$ \\
\hline 18 & $\begin{array}{l}\text { Apa kaitan gradien garis singgung dengan } \\
\text { turunan? }\end{array}$ \\
\hline 19 & $\begin{array}{l}\text { Kapan penggunaan notasi Leibniz dan notasi } \\
\text { newton disarankan? }\end{array}$ \\
\hline 20 & $\begin{array}{l}\text { Adakah fungsi yang tidak dapat dicari } \\
\text { turunannya pada sutatu titik? }\end{array}$ \\
\hline 21 & $\begin{array}{l}\text { Apa perbedaan turunan pada sebuah titik } \\
\text { dan pada sebuah himpunan? }\end{array}$ \\
\hline 22 & $\begin{array}{l}\text { Adakah fungsi yang tidak dapat dicari } \\
\text { turunannya? }\end{array}$ \\
\hline
\end{tabular}

Aspek pertama yang akan dilihat pada Tabel 8, 9, dan 10 adalah panjang Story Arc. Panjang yang dimaksud adalah banyaknya cell yang berwarna abu-abu pada setiap baris pertanyaan. Sebagai contoh,
Pertanyaan 4 pada Tabel 8 memiliki panjang lima. Selanjutnya, jika ratarata panjang story arc dihitung, maka diperoleh bahwa buku 2017 dan 2014 mendapat skor 1,77 , buku 2009 memperoleh 1,71, dan buku 2008 memperoleh 1,50. Hal ini mengisyaratkan bahwa buku 2017 dan 2014 memiliki peluang yang lebih besar untuk membuat pembaca penasaran dan ingin tahu terhadap isi cerita matematis yang ada di buku. Hal ini disebabkan karena beberapa pertanyaan tidak langsung terjawab pada saat aksi dimana ia pertama kali muncul. Akibatnya, pembaca akan terus bergerak maju melanjutkan bacaan sampai pada aksi dimana pertanyaan tersebut terjawab secara penuh. Lebih lanjut, tren positif dari tahun 2008 ke 2017 menunjukkan kemajuan buku Indonesia pada aspek ini.

Tabel 6. Pertanyaan yang Muncul pada Buku 2009

\begin{tabular}{ll}
\hline No & Pertanyaan \\
\hline 1 & $\begin{array}{l}\text { Apa definisi dari turunan? } \\
\text { Apa yang dimaksud dengan kalkulus } \\
\text { differensial? }\end{array}$ \\
3 & $\begin{array}{l}\text { Bagaimana cara menyelesaikan masalah } \\
\text { tadi dengan mengguunakan turunan? }\end{array}$ \\
4 & $\begin{array}{l}\text { Seperti apa bentuk limit yang disebut } \\
\text { turunan yang muncul secara meluas di }\end{array}$ \\
5 & $\begin{array}{l}\text { pelbagai bidang? } \\
\text { Adakah fungsi yang tidak dapat dicari } \\
\text { turunannya? }\end{array}$ \\
6 & $\begin{array}{l}\text { Adakah kriteria dari himpunan asal } \\
\text { dimana fungsi dapat diturunkan? }\end{array}$ \\
7 & $\begin{array}{l}\text { Apa kriteria dari sebuah fungsi sehingga } \\
\text { dapat diturunkan? }\end{array}$ \\
\hline
\end{tabular}

Aspek selanjutnya adalah ketebalan Story Arc yang ditentukan dengan cara menghitung banyaknya cell berwarna abu-abu yang terdapat pada setiap kolom aksi. Sebagai contoh, Aksi 1 pada Tabel 8 mempunyai ketebalan lima. Dengan menghitung rata-rata ketebalan pada tiap tabel diperoleh bahwa buku 2017 dan 2014 memperoleh 5,57, buku 2009 memperoleh 4,00 dan buku 2008 memperoleh 4,50. Hasil ini mengindikasikan bahwa 
cerita matematis pada buku 2017 dan 2014 memberikan beraneka segi pelajaran. Hal ini diakibatkan karena sebuah aksi melibatkan beberapa pertanyaan yang artinya ada beberapa ide Matematika yang masuk dalam satu aksi. Lebih lanjut, hasil ini menunjukkan adanya kecenderungan positif dari buku Matematika Indonesia, walaupun ada penurunan dari buku 2008 ke buku 2009.

Tabel 7. Pertanyaan yang Muncul pada Buku 2008

\begin{tabular}{|c|c|}
\hline No & Pertanyaan \\
\hline 1 & Apa yang disebut dengan turunan? \\
\hline 2 & $\begin{array}{l}\text { Apa yang disebut dengan } \\
\text { kemonotonan? }\end{array}$ \\
\hline 3 & $\begin{array}{l}\text { Apa yang disebut dengan ekstrim } \\
\text { fungsi? }\end{array}$ \\
\hline 4 & $\begin{array}{l}\text { Apa yang disebut dengan } \\
\text { kecekungan? }\end{array}$ \\
\hline 5 & $\begin{array}{l}\text { Apa yang disebut dengan titik balik } \\
\text { fungsi? }\end{array}$ \\
\hline 6 & $\begin{array}{l}\text { Bagaimana cara menyelesaikan } \\
\text { masalah tersebut dengan } \\
\text { menggunakan turunan? }\end{array}$ \\
\hline 7 & $\begin{array}{l}\text { Mengapa persamaan garis singgung } \\
\text { tidak boleh tegak lurus dengan } \\
\text { sumbu x? }\end{array}$ \\
\hline 8 & $\begin{array}{l}\text { Apa kaitan gradien garis singgung } \\
\text { dengan turunan? }\end{array}$ \\
\hline 9 & $\begin{array}{l}\text { Apakah setiap titik pada fungsi } \\
\text { memiliki garis singgung? }\end{array}$ \\
\hline 10 & $\begin{array}{l}\text { Apa kaitan kecepatan sesaat dengan } \\
\text { turunan? }\end{array}$ \\
\hline 11 & $\begin{array}{l}\text { Apakah setiap fungsi jarak tempuh } \\
\text { dapat dicari kecepatan sesaatnya? }\end{array}$ \\
\hline 12 & $\begin{array}{l}\text { Dapatkah kita mencari suatu fungsi } \\
\text { yang menyatakan kecepatan sesaat } \\
\text { pada suatu selang atau rentang } \\
\text { waktu tertentu? }\end{array}$ \\
\hline 13 & $\begin{array}{l}\text { Apakah setiap fungsi dapat } \\
\text { diturunkan? }\end{array}$ \\
\hline 14 & $\begin{array}{l}\text { Adakah syarat supaya fungsi dapat } \\
\text { diturunkan? }\end{array}$ \\
\hline 15 & Kapan kita menggunakan notasi ini? \\
\hline 16 & Apa keunggulan notasi Leibniz? \\
\hline 17 & $\begin{array}{l}\text { Apa manafaat mengetahui } \\
\text { bagaimana cara menentukan } \\
\text { turunan fungsi yang hasilnya berupa } \\
\text { fungsi? }\end{array}$ \\
\hline 18 & $\begin{array}{l}\text { Apa kaitan turunan pada suatu } \\
\text { himpunan dengan turunan pada } \\
\text { sebuah titik? }\end{array}$ \\
\hline
\end{tabular}

Tabel 8. Story Arc pada buku 2017 dan 2014 yang sesuai dengan Tabel 5

\begin{tabular}{|c|l|l|l|l|l|l|l|}
\hline $\mathbf{P}$ & $\mathbf{A 1}$ & $\mathbf{A 2}$ & $\mathbf{A 3}$ & $\mathbf{A 4}$ & $\mathbf{A 5}$ & $\mathbf{A 6}$ & $\mathbf{A 7}$ \\
\hline 1 & & & & & & & \\
\hline 2 & & & & & & & \\
\hline 3 & & & & & & & \\
\hline 4 & & & & & & & \\
\hline 5 & & & & & & & \\
\hline 6 & & & & & & & \\
\hline 7 & & & & & & & \\
\hline 8 & & & & & & & \\
\hline 9 & & & & & & & \\
\hline 10 & & & & & & & \\
\hline 11 & & & & & & & \\
\hline 12 & & & & & & & \\
\hline 13 & & & & & & & \\
\hline 14 & & & & & & & \\
\hline 15 & & & & & & & \\
\hline 16 & & & & & & & \\
\hline 17 & & & & & & & \\
\hline 18 & & & & & & & \\
\hline 19 & & & & & & & \\
\hline 20 & & & & & & & \\
\hline 21 & & & & & & & \\
\hline 22 & & & & & & & \\
\hline
\end{tabular}

Tabel 9. Story Arc pada buku 2009 yang bersesuaian dengan Tabel 6

\begin{tabular}{|r|l|l|l|}
\hline $\mathbf{P}$ & $\mathbf{A 1}$ & $\mathbf{A 2}$ & $\mathbf{A 3}$ \\
\hline 1 & & & \\
\hline 2 & & & \\
\hline 3 & & & \\
\hline 4 & & & \\
\hline 5 & & & \\
\hline 6 & & & \\
\hline 7 & & & \\
\hline
\end{tabular}

Tabel 10. Story Arc pada buku 2008 yang bersesuaian dengan Tabel 7

\begin{tabular}{|c|l|l|l|l|l|l|}
\hline $\mathbf{P}$ & A1 & A2 & A3 & A4 & A5 & A6 \\
\hline 1 & & & & & & \\
\hline 2 & & & & & & \\
\hline 3 & & & & & & \\
\hline 4 & & & & & & \\
\hline 5 & & & & & & \\
\hline 6 & & & & & & \\
\hline 7 & & & & & & \\
\hline 8 & & & & & & \\
\hline 9 & & & & & & \\
\hline 10 & & & & & & \\
\hline 11 & & & & & & \\
\hline 12 & & & & & & \\
\hline 13 & & & & & & \\
\hline 14 & & & & & & \\
\hline 15 & & & & & & \\
\hline 16 & & & & & & \\
\hline 17 & & & & & & \\
\hline 18 & & & & & & \\
\hline
\end{tabular}




\section{Simpulan}

Dalam pandangan kerangka konspetual Turunan menurut Zandieh (2000), semua buku mengakomodasi sekitar setengah dari semua kategori yang ada. Buku 2008 merupakan buku yang paling luas bahasannya. Dalam hal kedalaman materi, penjelasan turunan sebagai fungsi terbatas hanya pada konteks simbol saja. Selanjutnya, dengan menggunakan kerangka berpikir bahwa teks Matematika adalah sebuah narasi, buku 2017 dan 2014 memiliki kesempatan yang paling besar untuk memikat pembaca. Selain itu buku yang paling banyak melibatkan berbagai sudut pandang dan ide Matematika adalah buku 2017 dan 2014.

\section{Batasan}

Dalam penelitian ini penulis membatasi analisis pada buku pemerintah saja dan hanya memilih dalam rentang waktu tertentu. Akibatnya, penelitian ini belum mampu menjelaskan bagaimana perkembangan buku Indonesia dari waktu ke waktu, terutama dalam hal pemaparan konsep Turunan. Selain itu, penggunaan teori narasi dengan tidak melibatkan kode plot matematis (lih. Zandieh dan Richman, 2017). Konsekuensinya, penelitian ini tidak memberikan penjelasan bagaimana progres dari sebuah pertanyaan yang muncul di dalam teks Matematika. Di lain pihak, penelitian ini juga hanya menyingkap apakah suatu pertanyaan yang muncul dibahas atau tidak dalam teks.

\section{Referensi}

Beaton, A. E., Mullis, I. V. Martin, M. O., Gonzalez, E. J., Kelly, D. L., \& Smith, T. A. (1996). Mathematics achievement in the middle school years: IEA's third international mathematics and science study (TIMSS). Boston, MA: Center for the Study of Testing, Evaluation, and Educational Policy, Boston College.

Biza, I. (2017). "Points" "slopes" and "derivatives": Substantiations of narratives about tangent line in university mathematics students' discourses. In 10th Conference of European Research in Mathematics Education.

Blank, A. A. (1960). Remarks on the teaching of calculus in the secondary school. The Mathematics Teacher, 53(7), 537-539.

Bressoud D., Ghedamsi I., Martinez-Luaces V., Törner G. (2016). Teaching and Learning of Calculus. In: Teaching and Learning of Calculus. ICME-13 Topical Surveys. Springer, Cham

Dietiker, L. (2013). Mathematical texts as narrative: Rethinking curriculum. For the Learning of Mathematics, 33(3), 14-19.

Dietiker, L. (2015). Mathematical story: a metaphor for mathematics curriculum. Educational Studies in Mathematics, 90(3), 285-302.

Dietiker, L. \& Richman, A. "When is an exploration exploratory? A comparative analysis of geometry lessons." The 2nd International Conference on Mathematics Textbook Research and Development (ICMT2) Conference. Rio de Janeiro, Brazil, 2017-05-07 - 2017-05-11

Fan, L. (2013). Textbook research as scientific research: towards a common ground on issues and methods of research on mathematics textbooks. $Z D M, 45(5), 765-777$. 
Jones, S. R. (2017). An exploratory study on student understandings of derivatives in real-world, non-kinematics contexts. The Journal of Mathematical Behavior, 45, 95-110.

Jones, S. R., \& Watson, K. L. (2017). Recommendations for a "Target Understanding" of the Derivative Concept for First-Semester Calculus Teaching and Learning. International Journal of Research in Undergraduate Mathematics Education, 1-29.

Kementrian Pendidikan dan Kebudayaan. (2016). Peraturan Menteri Pendidikan dan Kembudayaan Tahun 2016 Nomor 24 Lampiran 16

Krippendorff, K. (2004). Content Analysis: An Introduction to Its Methodology. SAGE Publications.

Orton, A. (1983). Students' understanding of differentiation. Educational Studies in Mathematics, 14(3), 235-250.

Park, J. (2013). Is the derivative a function? If so, how do students talk about it?. International Journal of Mathematical Education in Science and Technology, 44(5), 624-640.

Park, J. (2015). Is the derivative a function? If so, how do we teach it?. Educational Studies in Mathematics, 89(2), 233-250.

Robinson, W. B. (1970). The effects of two semesters of secondary school calculus on students' first and second quarter calculus grades at the University of Utah. Journal for Research in Mathematics Education, 1(1) 57-60.

Roorda, G., Vos, P., Drijvers, P., \& Goedhart, M. (2016). Solving rate of change tasks with a graphing calculator: a case study on Instrumental Genesis. Digital Experiences in Mathematics Education, 2(3), 228-252.

Samuels, J. (2017). A Graphical Introduction to the Derivative. Mathematics Teacher, $111(1), 48-53$.

Sun, Y., Kulm, G., \& Capraro, M. M. (2009). Middle grade teachers' use of textbooks and their classroom instruction. Journal of Mathematics Education, 2(2), 20-37.

Thompson, D. R., Senk, S. L., \& Johnson, G. J. (2012). Opportunities to learn reasoning and proof in high school mathematics textbooks. Journal for Research in Mathematics Education, 43(3), 253-295.

Törner, G., Potari, D., \& Zachariades, T. (2014). Calculus in European classrooms: curriculum and teaching in different educational and cultural contexts. ZDM, 46(4), 549-560.

Valverde, G., Bianchi, L., Wolfe, R., Schmidt,W. \& Houang, R. (2002). According to the book: Using TIMSS to investigate the translation of policy into practice through the world of textbooks. Dordrecht, The Netherlands: Kluwer.

Verhoef, N. C., Coenders, F., Pieters, J. M., van Smaalen, D., \& Tall, D. O. (2015). Professional development through lesson study: teaching the derivative using GeoGebra. Professional development in education, 41(1), 109-126.

Weigand, H.-G. (2014). A discrete approach to the concept of derivative. ZDM Mathematics Education, 46, 603-619.

Wijaya, A., Van den Heuvel-Panhuizen, M., \& Doorman, M. (2015). Opportunityto-learn context-based tasks provided by mathematics textbooks. Educational studies in Mathematics, 89, 41-65.

Zandieh, M. (2000). A theoretical framework for analyzing student understanding of the concept of derivative. CBMS Issues in Mathematics Education, 8, 103-127.

Zandieh, M. J., \& Knapp, J. (2006). Exploring the role of metonymy in mathematical understanding and reasoning: The concept of derivative as an example. The Journal of Mathematical Behavior, 25(1), 1-17. 